\title{
American Opportunity Credit: Key To Education For Lower And Middle Income College Students
}

Robin Guerrero, MBA, EA, University of the Incarnate Word, USA Theresa Tiggeman, MBA, CPA, University of the Incarnate Word, USA Tracie Edmond, Ph.D., University of the Incarnate Word, USA

\begin{abstract}
The Tax Relief Act of 1997 created an important tax provision which helped taxpayers offset the cost of higher education. This provision was in the form of education tax credits. Because a tax credit is a dollar for dollar reduction in tax liability, these education credits were designed to reduce the amount of tax due for college students or their parents. Introduced in 1998, and known as the Hope Scholarship and the Lifetime Learning tax credits, these credits were established to counterbalance the monies spent on tuition, fees, and some course materials during postsecondary education. While these credits proved to be beneficial to many taxpayers over the past decade, most recently, the signing of the American Recovery and Reinvestment Act (ARRA) of 2009 provided a new provision which was intended to increase access to education and to stimulate the economy. The ARRA of 2009 established for two years (2009 and 2010) the "American Opportunity" tax credit as a replacement for the Hope credit. Similar to the previous education credits, the American Opportunity tax credit helps students and families pay for post-secondary education. However, the most significant condition of this credit is that 40\% of the American Opportunity tax credit is refundable and therefore available to households with little or no tax liability. Since refundable credits generate refunds over and above the withholding amount instead of just reducing the tax liability, the American Opportunity tax credit is available to the lowest income tax payers. As a result, it is possible for many taxpayers to receive a maximum amount of refundable credit of up to \$1,000. Unfortunately, the American Opportunity credit is proposed to be available only on a taxpayer's 2009 and 2010 tax return. After this time, the credit is expected to revert to its original form prior to the ARRA of 2009. Many taxpayers will no longer be eligible for the refundable portion of the credit nor many of its other beneficial provisions. Therefore, the purpose of this paper is to demonstrate the effectiveness of the new American Opportunity Credit and to show the need for the continuance of this credit that is not only crucial for the welfare of the lower to middle income taxpayers but the larger, refundable credit would extend educational assistance to low to moderate income students, making it easier for them or their parents to afford college and thus encouraging attendance.
\end{abstract}

Keywords: taxation; education tax credits; refundable tax credits; nonrefundable tax credits; college education; college students; American Opportunity Credit; Hope Credit; Lifetime Learning Credit; American Recovery and Reinvestment Act (ARRA) of 2009; Tax Relief Act of 1997; low income taxpayers

\section{INTRODUCTION}

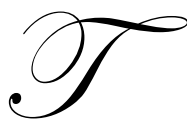

o help students and their families struggling to cope with the increasing costs of college and higher education and to promote the growth in attendance for post secondary education, Congress decided to enact a bill that would benefit both parties. On August $5^{\text {th, }}$ 1997, the Tax Relief Act of 1997 was signed into legislation. This act created an important tax provision which allowed taxpayers to offset the burden of 
higher education cost. This provision was in the form of two education tax credits designed to reduce the amount of tax due for college students or their parents (IRC Sec. 25A). Introduced in 1998, these education tax credits were known as the Hope Scholarship (IRC Sec. 25A (a)(1)) and Lifetime Learning (IRC Sec. 25A(a)(2)) tax credits. These credits were established to counterbalance the amount of money spent on tuition, fees, and course materials during postsecondary education.

When President Clinton signed the legislation into law, he and many others believed the two tax credits would increase college access and make college more affordable for many Americans. Indeed, the Congressional Budget Office estimated that in their first five years of existence, the Hope and Lifetime Learning benefits would provide nearly $\$ 40$ billion in new funding for college students and their families (National Association of Student Financial Aid Administrators, n.d.).

\section{THE HOPE SCHOLARSHIP \& LIFETIME LEARNING CREDITS}

According to the Internal Revenue Service, (IRS), generally, a taxpayer can claim the Hope or Lifetime Learning Credit if they paid qualified tuition and related expenses to an eligible education institution of higher education for an eligible student who is either the taxpayer, the taxpayer's spouse, or a dependent whom the taxpayer can claim an exemption on his or her tax return. (IRS Publication 970, 2009).

According to Section 25A(b) of the Internal Revenue Code, prior to tax year 2009, to be eligible for the Hope credit, the student must be enrolled in a program that leads to a degree, certificate or other recognized educational credential, taking at least one-half of the normal full-time workload for his or her course of study for at least one academic period beginning during the calendar year, and has not completed the first two years of postsecondary education. In addition, the related expenses associated with the Hope credit included fees paid for course-related books, supplies, equipment, and student activities. Most importantly, related expenses are considered a qualifying expense only if the fees must be paid to the institution as a condition of enrollment or attendance.

When a taxpayer or his or her dependent is no longer eligible for a Hope Credit, the taxpayer may be able to claim a Lifetime Learning credit instead. The Lifetime Learning credit, from Section $25 \mathrm{~A}(\mathrm{c})$ of the Internal Revenue Code, is based on the total qualified education expenses paid by the taxpayer and not on the number of eligible students. Educational expenses are qualified for the Lifetime Learning credit for courses taken as part of a postsecondary degree program, or courses that are not part of a postsecondary degree program, but are taken to improve or acquire job skills. However, unlike the Hope credit, the Lifetime Learning credit differs in that it is allowed for one or more courses, non-degree courses taken to improve job skills are eligible, expenses related to noncredit courses are allowed and there is no limit to number of years credit can be claimed.

\section{THE AMERICAN OPPORTUNITY CREDIT}

While these credits proved to be beneficial to many taxpayers over the past decade, the National Association for Student Financial Aid Administrators (n.d.) states the credits did not increase attendance in college because "unlike the traditional student aid programs, the primary beneficiaries of the Hope and Lifetime Learning tax credits are middle-income students" and not low income students. However, most recently, the signing of the American Recovery and Reinvestment Act (ARRA) of 2009 provided a new provision which targets low and middle income taxpayers and was intended to stimulate the economy. The ARRA of 2009 created the "American Opportunity" tax credit (IRC Sec. 25A(i)) as a replacement for the Hope credit. Similar to the previous education credits, the American Opportunity tax credit helps students and families pay for post-secondary education.

Jackson (2010) notes that the "use of temporary tax laws to counter an overheated or sluggish economy will continue as long as federal tax policy plays a central role in combating cyclical swings." The economy will benefit as both lower and middle income taxpayers will realize additional cash from the American Opportunity credit. The new education credit, temporary for tax years 2009 and 2010, modifies the existing Hope Credit making the credit available to a broader range of taxpayers, including many with higher incomes (IRS 2010). The new credit also adds required course materials not paid directly to the institution to the list of qualifying expenses and allows the credit to 
be claimed for four post-secondary education years instead of two. Many of those eligible will qualify for the maximum annual credit of $\$ 2,500$ per student (IRS, Pub 970, 2009).

However, the most significant condition of the American Opportunity credit is that those who owe no tax are now eligible for the credit (IRS 2010). Under the new provisions, $40 \%$ of the American Opportunity tax credit may refundable and therefore available to households with little or no tax liability (IRS 2010). As a result, it is possible for many taxpayers eligible for the American Opportunity to receive a maximum amount of refundable credit of up to $\$ 1,000$.

\section{COLLEGE AND UNIVERSITY PERSPECTIVE}

While the U.S. is in the midst of its worst recession in recent history, colleges and universities are experiencing budget cuts and other funding declines. A State Higher Education Executive Officers (2010) report states that, in 2009, support for higher education decreased by $\$ 2.8$ billion. Fortunately, federal education stimulus dollars of $\$ 2.4$ billion compensated for this decrease. However, the report notes the "the enrollment boom hit a record high of 10.8 million students at public institutions." According to the report, this is an increase of 3.4 percent between 2008 and 2009 and the student's share of the tuition increased by 2.6 percent in the last five years. Essentially, more students are attending higher education institutions and are paying a larger percentage of the tuition cost. Garrison and Cummings (2010) point out that, in light of the current recession, a terminated worker "may need additional education or retraining to re-enter the job market" which puts even more pressure on our colleges and universities. Rosenberg and Schuldenfrei (2010) state the American Recovery and Reinvestment Act was designed to help the economy, and promote job growth and education. These authors relate that the American Opportunity credit is intended to "help defray the soaring costs of higher education." Additionally, Rosenberg and Schuldenfrei feel that there is "hope that Congress will make these changes permanent." The authors of this paper echo this sentiment.

\section{PURPOSE OF STUDY}

The passing in law of the American Recovery and Reinvestment Act of 2009 has provided many new opportunities for the enhancement of the Hope or the American Opportunity education tax credit. Unfortunately, the American Opportunity credit is proposed to be available only a taxpayer's 2009 and 2010 tax return. After this time, the credit is expected to revert to its original form prior to the ARRA of 2009. As a result, many taxpayers will no longer be eligible for the refundable portion of the credit nor many of its other beneficial provisions. According to the Tax Policy Center of the Urban Institute and the Brooking Institution (2010), the president proposes to make the credit permanent and index it for inflation both the maximum expenditures eligible for the credit and the income thresholds which the credit phases out. Therefore, the purpose of this paper is to demonstrate the effectiveness of the new American Opportunity Credit and to show the need for the continuance of this credit. 
The following chart is provided as a reference and compares and contracts the various tax benefits for higher education.

\begin{tabular}{|c|c|c|c|c|c|c|}
\hline \multicolumn{7}{|c|}{$\begin{array}{l}\text { Highlights of Education Tax Benefits for Tax Year } 2009 \\
\text { This chart highlights some differences among the benefits discussed in this publication. See the text for de finitions and } \\
\text { details. Do not rely on this chart alone. } \\
\text { Caution: You generally cannot daim more than one benefit for the same education expense. }\end{array}$} \\
\hline & $\begin{array}{l}\text { Scholarships, } \\
\text { Fellowships, } \\
\text { Grants, and } \\
\text { Tuition } \\
\text { Reductions }\end{array}$ & $\begin{array}{l}\text { American } \\
\text { Opportunity } \\
\text { Credit }\end{array}$ & Hope Credit & $\begin{array}{l}\text { Lifetime } \\
\text { Learning Credit }\end{array}$ & $\begin{array}{l}\text { Student Loan } \\
\text { Interest } \\
\text { Deduction }\end{array}$ & $\begin{array}{l}\text { Tuition and Fees } \\
\text { Deduction }\end{array}$ \\
\hline $\begin{array}{l}\text { What is your } \\
\text { benefit? }\end{array}$ & $\begin{array}{l}\text { Amounts received } \\
\text { may not be } \\
\text { taxable }\end{array}$ & $\begin{array}{l}40 \% \text { of credit may } \\
\text { be refundable } \\
\text { (limited to } \$ 1,000 \text { ) }\end{array}$ & \multicolumn{2}{|c|}{$\begin{array}{l}\text { Credits can reduce amount of tax you } \\
\text { must pay }\end{array}$} & $\begin{array}{l}\text { Can deduct } \\
\text { interest paid }\end{array}$ & $\begin{array}{l}\text { Can deduct } \\
\text { expenses }\end{array}$ \\
\hline $\begin{array}{l}\text { What is the } \\
\text { annual limit? }\end{array}$ & None & $\$ 2,500$ & $\begin{array}{l}\$ 1,800 \text { credit } \\
(\$ 3,600 \text { if a } \\
\text { student in a } \\
\text { Midwestern } \\
\text { disaster area) per } \\
\text { student }\end{array}$ & $\begin{array}{l}\$ 2,000 \text { credit } \\
(\$ 4,000 \text { if a } \\
\text { student in a } \\
\text { Midwestern } \\
\text { disaster area) per } \\
\text { tax retum }\end{array}$ & $\$ 2,500$ deduction & $\$ 4,000$ deduction \\
\hline $\begin{array}{l}\text { What expenses } \\
\text { qualify besides } \\
\text { tuition and } \\
\text { required } \\
\text { enrollment fees? }\end{array}$ & $\begin{array}{l}\text { Course-related } \\
\text { expenses such as } \\
\text { fees, books, } \\
\text { supplies, and } \\
\text { equipment }\end{array}$ & $\begin{array}{l}\text { Course-related } \\
\text { books, supplies, } \\
\text { and equipment }\end{array}$ & $\begin{array}{l}\text { None (but } \\
\text { seeStudents in } \\
\text { Midwestem } \\
\text { disaster areas } \\
\text { under Qualified } \\
\text { Educa fion } \\
\text { Expen ses in } \\
\text { chapter } 3 \text { for an } \\
\text { exception) }\end{array}$ & $\begin{array}{l}\text { None (but see } \\
\text { Students in } \\
\text { Midwestem } \\
\text { disaster areas } \\
\text { under Qualified } \\
\text { Education } \\
\text { Expenses in } \\
\text { chapter } 4 \text { for an } \\
\text { exception) }\end{array}$ & $\begin{array}{l}\text { Books } \\
\text { Supplies } \\
\text { Equipment } \\
\text { Room \& board } \\
\text { Transportation } \\
\text { Other necessary } \\
\text { expenses }\end{array}$ & $\begin{array}{l}\text { None (but see } \\
\text { Students in } \\
\text { Midwestem } \\
\text { disaster areas } \\
\text { under Qualified } \\
\text { Education } \\
\text { Expenses in } \\
\text { chapter } 7 \text { for an } \\
\text { exception) }\end{array}$ \\
\hline $\begin{array}{l}\text { What education } \\
\text { qualifies? }\end{array}$ & $\begin{array}{l}\text { Undergraduate \& } \\
\text { graduate } \\
K-12\end{array}$ & $\begin{array}{l}\text { 1st } 4 \text { years of } \\
\text { undergraduate } \\
\text { (postsecondary) }\end{array}$ & $\begin{array}{l}\text { 1st } 2 \text { years of } \\
\text { undergraduate } \\
\text { (postsecondary) }\end{array}$ & $\begin{array}{l}\text { Undergraduate \& } \\
\text { graduate } \\
\text { Courses to } \\
\text { acquire or } \\
\text { improve job skills }\end{array}$ & $\begin{array}{l}\text { Undergraduate \& } \\
\text { graduate }\end{array}$ & $\begin{array}{l}\text { Undergraduate \& } \\
\text { graduate }\end{array}$ \\
\hline $\begin{array}{l}\text { What are some } \\
\text { of the other } \\
\text { conditions that } \\
\text { apply? }\end{array}$ & $\begin{array}{l}\text { Must be in degree } \\
\text { or vocational } \\
\text { program } \\
\text { Payment of tuition } \\
\text { and required fees } \\
\text { must be allowed } \\
\text { under the grant }\end{array}$ & $\begin{array}{l}\text { Can be claimed } \\
\text { for only } 4 \text { tax } \\
\text { years (which } \\
\text { includes years } \\
\text { Hope credit } \\
\text { claimed) } \\
\text { Must be enrolled } \\
\text { at least half-time } \\
\text { in degree } \\
\text { program } \\
\text { No felony drug } \\
\text { conviction(s) } \\
\text { Cannot claim } \\
\text { Hope credit on } \\
\text { same return }\end{array}$ & $\begin{array}{l}\text { Can be claimed } \\
\text { for only } 2 \text { tax } \\
\text { years } \\
\text { Must be enrolled } \\
\text { at least half-time } \\
\text { in degree } \\
\text { program } \\
\text { Must claim the } \\
\text { credit for at least } \\
\text { one eligible } \\
\text { Midwestern } \\
\text { disaster area } \\
\text { student } \\
\text { No felony drug } \\
\text { conviction(s) } \\
\text { Cannot claim } \\
\text { American } \\
\text { opportunity credit } \\
\text { on same retum }\end{array}$ & $\begin{array}{l}\begin{array}{l}\text { No other } \\
\text { conditions }\end{array} \\
\end{array}$ & $\begin{array}{l}\text { Must have been } \\
\text { at least half-time } \\
\text { student in degree } \\
\text { program }\end{array}$ & $\begin{array}{l}\text { Cannot claim both } \\
\text { deduction \& } \\
\text { education credit } \\
\text { for same student } \\
\text { in same year }\end{array}$ \\
\hline $\begin{array}{l}\text { In what income } \\
\text { range do } \\
\text { benefits } \\
\text { phase out? }\end{array}$ & No phaseout & $\begin{array}{l}\$ 80,000- \\
\$ 90,000 \\
\$ 160,000- \\
\$ 180,000 \text { for joint } \\
\text { returns }\end{array}$ & \multicolumn{2}{|c|}{$\begin{array}{l}\$ 50,000-\$ 60,000 \\
\$ 100,000-\$ 120,000 \text { for joint retums }\end{array}$} & $\begin{array}{l}\$ 60,000- \\
\$ 75,000 \\
\$ 120,000- \\
\$ 150,000 \text { for } \\
\text { joint retums }\end{array}$ & $\begin{array}{l}\$ 65,000- \\
\$ 80,000 \\
\$ 130,000- \\
\$ 160,000 \text { for } \\
\text { joint retums }\end{array}$ \\
\hline
\end{tabular}

Source: Internal Revenue Service 2009 Publication 970, Tax Benefits for Higher Education

\section{PARTICIPANTS}

In building a sample for this study, it was determined to target a particular group of taxpayers with a set of criteria. The first requirement was locating taxpayers who were college students or had qualified dependents that 
were enrolled in a college or university during the 2009 tax year. The second requirement was locating taxpayers who were eligible for the American Opportunity credit. These criteria were necessary to ensure that the taxpayer could potentially benefit from this tax credit. Based on the selection criteria, 33 taxpayers satisfied the requirements to participate in this study.

\section{LIMITATIONS OF THE STUDY}

Unfortunately, as with any research, there are certain limitations of this study. In this particular case, the first limitation of the study was the sample size of only 33 taxpayers. The sample size was limited because of the criteria chosen to be used to conduct this research. Therefore, the sample size may not be representative of the entire population. Finding qualifying individuals resulted in a small sample pull. Secondly, because of the uniqueness of this topic, prior research does not exist to compare this study to. As a result, all of the tests conducted, were original in format. Lastly, this study is limited to individuals that were previously existing clients of the researcher. The ability for a random sample was not available due to time constraints and availability.

\section{COLLECTION AND EXAMINATION OF DATA}

In order to conduct this research, the tax returns of each participant for the previous tax year (2009) were examined. From this information, data taken from these returns included the taxpayers' Adjusted Gross Income (AGI), the amounts of their tax liabilities, the amounts of their education credits, and the amounts of their American Opportunity Refundable Credits. The amount of the taxpayer's refund was not taken into consideration for this study because of varying differences in federal withholdings, other refundable credits and estimated tax payments among taxpayers. The results portrayed here in this study are taken from the actual returns of taxpayers who have demonstrated some benefits from the new American Opportunity Credit

\section{FINDINGS}

For many taxpayers eligible for the Hope education credit, the new rules associated with the American Opportunity Credit has demonstrated many true benefits. Realize that the American Opportunity tax credit can generate two credits: the nonrefundable potion which is used to offset tax liability and the refundable potion which acts as an additional refund amount. This amount is refunded after the tax liability is satisfied. Therefore, this credit is most valuable for very low income taxpayers who may have little or no tax liability. In this study, for most of the taxpayers eligible for the refundable portion of the credit, the average refunded amount was $\$ 747$. This amount is lower than the maximum credit amount of $\$ 1,000$ since many taxpayers had qualifying expenses less than the $\$ 4000$ allowable expenditures for the tax year. In other instances, the education credit was used to offset higher tax liabilities, thus reducing or eliminating any refundable amounts.

One area of the American Opportunity credit which has assisted many taxpayers in 2009 was the provision for the qualifying expenses. In prior years, the related expenses associated with the Hope credit included fees paid for course-related books, supplies, equipment, and student activities were considered qualifying expenses only if the fees must be paid to the institution as a condition of enrollment or attendance. Under the new American Opportunity Credit, required course materials need not be paid to the institution in order to qualify (IRC Sec. 25A((f)(1)(A)). This provision is especially significant for many students attending college part time or are attending junior colleges. While for most full time students the cost of tuition alone for one semester of college exceeds the $\$ 4,000$ limitation per student for the qualifying expenses, for those attending college part-time, the full amount of the qualified expenses may not be attained. Now, with this new credit, student expenses not paid to the universities can now be added to the qualified expenses.

For example, in one instance a taxpayer taking one or two courses at a community college per semester may have qualifying costs paid to the college of $\$ 2833$ per year. Ordinarily, this would have resulted in a total tax credit of $\$ 2208$ ( $\$ 1,325$ for nonrefundable tax credit). However under the American Opportunity Credit, expenses for books, supplies, and equipment needed for a course of study are included in qualified education expenses whether or not the materials are purchased from the educational institution. In this instance the costs of books and other course related materials totaled another $\$ 740$ for the year. As a result, because of the new credit the amount of 
the qualified expense is now $\$ 3573$. Therefore the taxpayer is now eligible for education credit of $\$ 2,393$ ( $\$ 1436$ for the non refundable credit and $\$ 957$ for the refundable tax portion of the credit).

Another important provision which has also been advantageous for taxpayers is the change in eligibility for the Hope Credit. Under Section 25A(i)2 of the new law, the credit can be claimed for four post-secondary education years instead of two. In the study conducted, several instances of benefit occurred.

In many instances, individuals were in their third year of post-secondary education during 2009. Under the old rules of education credit (Sec. 25A(b)(2)(a)), these individuals would have no longer been eligible for the Hope Credit and would have had to have claimed the Lifetime Learning credit. If this had occurred, these individuals would have only been eligible for a credit worth $20 \%$ of their qualified expenses up to $\$ 2000$. In addition, the credit would have been non-refundable. Instead, under the rules of the new American Opportunity credit, these individuals are still eligible to claim the benefits of the former Hope Credit. This means that these individuals are still eligible for $100 \%$ of the first $\$ 2,000$ of qualified expenses plus $25 \%$ of their next $\$ 2,000$ of qualified expense or an education credit of up to $\$ 2,500$. In addition, this individual is now eligible for the refundable portion of the credit up to $\$ 1,000$ or ( $40 \%$ of the credit).

In another instance, during tax year 2009, an individual was in her fourth year of post-secondary education. In 2006 and 2007, this individual was eligible for the Hope Credit. In 2008, since this individual was in her third year of post-secondary education, she was no longer eligible for the Hope credit and was forced to claim a Lifetime Learning credit. In 2009, however, because of the new provisions American Opportunity Credit and the expansion for eligibility, this individual was once again able to claim the Hope credit on her return since she was in her fourth year of post-secondary education.

The most significant benefit from the new American Opportunity credit is the provision which makes a portion of this credit (up to 40\%) refundable. As previously mentioned, many low income taxpayers either in college or with dependents in college are now benefiting from this new refundable credit. Previously, many of these individuals would have not been eligible for any form of the credit because they did not have a tax liability. In other situations, low income taxpayers may have had a small tax liability that was fully paid off by part of their eligible credit. When this occurred, usually the remaining portion of the unused credit was lost. As a result of the new rules to the credit, these individuals are now eligible for the refundable portion of the credit.

In one instance a taxpayer, with two daughters in college, had an adjusted gross income of $\$ 32,000$ and no tax liability. Ordinarily, this individual would have not benefited from any education credit. The $\$ 4,577$ of qualified expenses for the two daughters would have not been used. However under the new provisions of the credit, the taxpayer was able to receive a refundable credit of $\$ 1,831$ ( $40 \%$ of the qualified expenses). As a result, the taxpayer was able to take this refunded amount and invest it into the tuition expenses for the daughters.

In another instance, a taxpayer had a son in his second year of college and an adjusted gross income of $\$ 37,400$. The qualified expenses for the year were $\$ 9,600$ (allowable qualified expenses limited to $\$ 4,000$ per student per year). After all adjustments and deductions, the taxpayer had a tax liability of $\$ 673$. Under the old provisions, the taxpayer would have been eligible for a tax credit of up to $\$ 2,500$. However, since her tax liability was only $\$ 673$ the amount of allowable Hope credit would have been limited to the $\$ 673$. Fortunately, under the new provisions of the law, the taxpayer was able to use $\$ 673$ of the credit to offset her tax liability and still was able to receive $40 \%$ of the allowable expenses or $\$ 1,000$ in a refundable credit. Once again this money was used to pay university costs.

\section{DISCUSSION AND CONCLUSION}

Since its inception, the creation of the education tax credits has benefited millions of taxpayers. According to IRS, more than 7.7 million taxpayers filed for an education credit on their 2008 tax returns accounting for nonrefundable tax credits of over $\$ 7.6$ million (IRS 2008). While a large portion of these credits may be attributed to the Lifetime Learning credit, many others still benefited from the rules of the Hope Scholarship Credit. 
For 2009's tax returns, because of the passing of the ARRA which restructured the Hope Credit into the American Opportunity Credit, as demonstrated in this study, many taxpayers have seen additional benefits from the new legislation because of these enhancements. The new American Opportunity Credit has not only made more individuals eligible for the credit, but has also allowed those with lower incomes or no tax liabilities to benefit from the refundable portion of the credit.

Unfortunately, in creating the American Opportunity Credit, Congress has only allowed these special provisions for the two tax filing years of 2009 and 2010. While the cost of education continues to rise, the continuance of these special provisions to the Hope credit is uncertain. As a result, the need for the continuance of the American Opportunity credit is not only crucial for the welfare of the lower to middle income taxpayers but will also aid in stimulating the economy. In addition, the larger, refundable credit would extend educational assistance to low to moderate income students, thus making it easier for them or their parents to afford college and thus encouraging their attendance.

\section{AUTHOR INFORMATION}

Robin Guerrero is an enrolled agent with a tax practice in San Antonio, Texas. Currently, he is a doctoral student and adjunct professor of taxation at the University of the Incarnate Word. For seventeen years, he has been a cocoordinator and technological expert for the university's Volunteers in Income Tax Program. Additionally, he designs and delivers tax training for the City of San Antonio's tax volunteers. He research interests include tax law, taxation training and education, and organizational leadership.

Theresa Tiggeman is a professor of accounting at the University of the Incarnate Word. Currently, her publications focus on current issues in taxation and collaborative learning in college classrooms. She has received awards for teaching and service to the community. She has been involved with the Volunteers in Income Tax Program for many years. She regularly speaks and writes on tax issues.

Dr. Tracie Edmond is an assistant professor of accounting at the University of the Incarnate Word in San Antonio, Texas. Her teaching philosophy focuses on service learning and collaborative learning utilizing actual fund raising activities to reinforce accounting theory and practice. To date, she and her students have raised over $\$ 20,000$ for local organizations. Her research interests include active learning, taxation and nonprofit. She is the co-coordinator for the university's Volunteers in Income Tax Program and the mother of three children.

\section{REFERENCES}

1. All returns: Sources of income, adjustments, deductions, credits, and tax items for 2008. (2008). Retrieved September 8, 2010, from Internal Revenue Service website: http://www.irs.gov/pub/irs-soi/08in13ms.xls

2. American opportunity credit [IRS Publication 970]. (2010, January 1). Retrieved September 8, 2010, from Internal Revenue Service website: http://www.irs.gov/publications/p970/ch02.html\#d0e1484

3. American Recovery and Reinvestment Act of 2009, 26 U.S.C. $§ 25$ A (RIA Checkpoint).

4. College access and tax credits. Retrieved September 21, 2010 from National Association of Student Financial and Aid Administrators website: http://www.nasfaa.org/Subhomes/ResearchHome/ College Access and Tax Credits .Pdf.

5. Garrison, L., \& Cummings, R. (2010). Global impact of tax considerations for displaced workers. The International Business \& Economics Research Journal, 9(9), 87-97. Retrieved September 22, 2010, from ABI/INFORM Global. (Document ID: 2127652501).

6. Fading stimulus saved colleges. (2010, September 22). Inside higher education. Retrieved September 22, 2010, from http://www.insidehighered.com/layout/set/print/news/2010/02/11/sheeo

7. Jackson, G. (2010). Lessons for tax planners. The CPA Journal, 80(8), 52-55. Retrieved September 22, 2010, from ABI/INFORM Global. (Document ID: 2133348831).Cooper, M. A. (n.d.).

8. Make permanent the American Opportunity tax credit. (n.d.). Tax policy center 2010 budget tax proposals. Retrieved September 8, 2010, from Urban Institute and Brookings Institute website: http://www.taxpolicycenter.org/taxtopics/Copy-of-Copy-of-2010_budget_AOTC.cfm 
9. Publication 970, Tax benefits for higher education. (2009). Internal Revenue Service. Rosenberg, D., \& Schuldenfrei, A. (2010). Education Expenses: An Analysis of the New American Opportunity Tax Credit. The CPA Journal, 80(2), 53-55. Retrieved September 22, 2010, from ABI/INFORM Global. (Document ID: 1967146211).

10. Tax Relief Act of 1997, 26 U.S.C. $§ 25 A$ (RIA Checkpoint). 